\title{
Meteorological factors driving glacial till variation and the associated periglacial debris flows in Tianmo Valley, south-eastern Tibetan Plateau
}

\author{
Mingfeng Deng ${ }^{1,2}$, Ningsheng Chen ${ }^{1}$, and Mei Liu ${ }^{1,2}$ \\ ${ }^{1}$ Key Laboratory of Mountain Hazards and Surface Process, Institute of Mountain Hazards \\ and Environment, Chinese Academy of Sciences, Chengdu 610041, China \\ ${ }^{2}$ College of Resources and Environment, University of Chinese Academy of Sciences, Beijing 100049, China
}

Correspondence: Ningsheng Chen (chennsh@imde.ac.cn)

Received: 27 July 2016 - Discussion started: 29 July 2016

Revised: 28 January 2017 - Accepted: 19 February 2017 - Published: 8 March 2017

\begin{abstract}
Meteorological studies have indicated that high alpine environments are strongly affected by climate warming, and periglacial debris flows are frequent in deglaciated regions. The combination of rainfall and air temperature controls the initiation of periglacial debris flows, and the addition of meltwater due to higher air temperatures enhances the complexity of the triggering mechanism compared to that of storm-induced debris flows. On the south-eastern Tibetan Plateau, where temperate glaciers are widely distributed, numerous periglacial debris flows have occurred over the past 100 years, but none occurred in the Tianmo watershed until 2007. In 2007 and 2010, three large-scale debris flows occurred in the Tianmo Valley. In this study, these three debris flow events were chosen to analyse the impacts of the annual meteorological conditions, including the antecedent air temperature and meteorological triggers. The remote sensing images and field measurements of the adjacent glacier suggested that sharp glacier retreats occurred in the 1 to 2 years preceding the events, which coincided with spikes in the mean annual air temperature. Glacial till changes providing enough active sediment driven by a prolonged increase in the air temperature are a prerequisite of periglacial debris flows. Different factors can trigger periglacial debris flows, and they may include high-intensity rainfall, as in the first and third debris flows, or continuous, long-term increases in air temperature, as in the second debris flow event.
\end{abstract}

\section{Introduction}

Alpine environments are vulnerable to climate change, and alpine glaciers and permafrost are particularly sensitive to degradation (Harris et al., 2009; IPCC, 2013). Glacier and permafrost retreat can induce mass movements such as landslides, shallow slides, debris slides, moraine collapses, etc. (Cruden and $\mathrm{Hu}$, 1993; Korup and Clague, 2009; McColl, 2012; Stoffel and Huggel, 2012; Fischer et al., 2012). These movements would bring the material out of the watersheds in the form of debris flows or sediment fluxes. Debris flows in alpine regions often bury residential areas, cut off main roads, block rivers (Shang et al., 2003; Cheng et al., 2005; Deng et al., 2013) and destroy basic facilities downstream; thus, they pose a considerable threat to the local economy and social development. In undeveloped alpine areas where the transportation system is particularly poor or limited, such as in south-eastern Tibet, the negative effects produced by debris flows, such as cutting off main roads, can be serious (Cheng et al., 2005).

Periglacial debris flows occur in high alpine areas with large areas of glaciers, such as on the Tibetan Plateau in China (Shang et al., 2003; Ge et al., 2014), in the Alps in Europe (Sattler et al., 2011; Stoffel and Huggel, 2012), in the Caucasus Mountains in Russia (Evans et al., 2009) and in northern Canada (Lewkowicz and Harris, 2005). Periglacial debris flows can be initiated by rainfall (Stoffel et al., 2011; Schneuwly-Bollschweiler and Stoffel, 2012), glacial meltwater flow or ice particle ablation (Arenson and Springman, 2005; Decaulne et al., 2005) or outburst floods from glacier 
lakes (Chiarle et al., 2007) in different parts of the world; however, multiple triggers of a single event have rarely been studied. Because debris flows are commonly triggered by rainfall (Sassa and Wang, 2005; Decaulne et al., 2007; Kean et al., 2013; Takahashi, 2014), the rainfall threshold, intensity and duration have been widely used for debris flow monitoring and to provide event warnings in non-glacier areas (Guzzetti et al., 2008).

In deglaciated areas, the debris flow threshold can be more difficult to determine. Periglacial debris flows tend to occur in the summer when the thawing of glaciers and glacial tills predominates and meltwater penetrates the glacial tills at a constant and successive flow rate. The effect of meltwater is similar to that of antecedent rainfall (Rahardjo et al., 2008) and is variable in different periods, considering snow and glacier shrinkage and air temperature fluctuations. In the Swiss Alps, the meltwater volume is high in early summer, and debris flows can be initiated by low-intensity rainfall. However, larger rainstorms are required to produce debris flows in late summer and early autumn when the meltwater volume is low (Stoffel et al., 2011; Schneuwly-Bollschweiler and Stoffel, 2012). On the south-eastern Tibetan Plateau, the rainfall threshold given by Chen et al. (2011) is relatively wide $\left(0.2-2.0 \mathrm{~mm} / 10 \mathrm{~min}, 0.6-6.3 \mathrm{~mm} \mathrm{~h}^{-1}\right.$ or 3.0 $19.4 \mathrm{~mm} / 24 \mathrm{~h}$ ), the small rainfall threshold of which is likely affected by the air temperature. Moreover, periglacial debris flows induced by sudden releases of water from glacier lakes are closely related to increasing air temperature (Liu et al., 2014).

Air temperature fluctuations are likely to be important triggers of periglacial debris flows. Compared to storm-induced debris flows, the addition of meltwater due to increased air temperature can greatly enhance the complexity of the initiation mechanism of periglacial debris flows. It is difficult to simulate the triggering process via experiments or mathematical simulation; thus, case studies of natural debris flows must be explored. In this study, three debris flow events in the Tianmo watershed on the south-eastern Tibetan Plateau are used as examples after a debris-flow-free period of nearly 100 years as deglaciation continues. The annual meteorological conditions, antecedent air temperature and triggering conditions prior to debris flows are analysed to further understand the meteorological triggers and their roles in glacier retreat, glacial till variation and debris flow initiation.

\section{Background}

\subsection{Study area}

Temperate glaciers on the Tibetan Plateau are primarily distributed in the Parlung Zangbo Basin, and they covered a total landmass of $2381.47 \mathrm{~km}^{2}$ in 2010 based on thematic mapper (TM) images (taken by the No. 4 or 5 TMs on the Landsat satellite with a spatial resolution of $30 \mathrm{~m}$ ) (Liu, 2013). His-

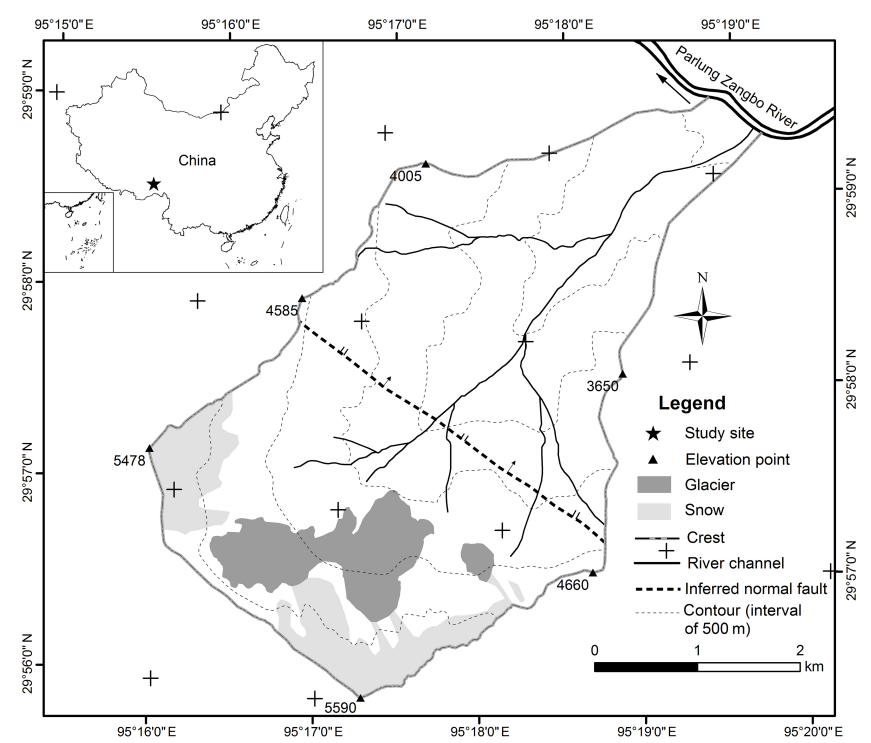

Figure 1. Location of Tianmo Valley and related information.

torically, the movement of temperate glaciers has produced numerous moraines, the depth of which can reach $500 \mathrm{~m}$ locally (Yuan et al., 2012). In recent decades, a significant temperature increase has occurred, and the temperature at the Bomi meteorological station (central Parlung Zangbo Basin) increased by $0.23^{\circ} \mathrm{C} / 10$ a from 1969 to 2007 , resulting in remarkable glacial shrinkage (Yang et al., 2010).

Tianmo Valley, which is located in Bomi County and to the south of the Parlung Zangbo River, covers an area of $17.76 \mathrm{~km}^{2}\left(29^{\circ} 59^{\prime} \mathrm{N} / 95^{\circ} 19^{\prime} \mathrm{E}\right.$; Fig. 1). This valley has a north-east-south-east orientation and is surrounded by high mountains reaching $5590 \mathrm{~m}$ a.s.l. at the southernmost location and $2460 \mathrm{~m}$ a.s.l. at the fork in the Parlung Zangbo River. The TM image from 2013 illustrated the presence of a hanging glacier with an area of $1.42 \mathrm{~km}^{2}$ in the upper concave area at an elevation of 4246 to $4934 \mathrm{~m}$. Bare rock, dipping at an angle of approximately $60^{\circ}$, emerges below and above the hanging glacier and is often covered by snow. Below $3800 \mathrm{~m}$ a.s.l., vegetation, including forest and shrubs, occupies most of the area (Table 1).

The river channel in the watershed is sheltered by shade and is not directly affected by sunlight, resulting in less solar radiation and a location at which a small trough glacier can form. In the main channel, the trough glacier extended to $2966 \mathrm{~m}$ a.s.l. in 2006. The lower part of the trough glacier has been eroded by glacier meltwater flow, and an arch glacier that is vulnerable to high pressure was formed (Fig. 2). The remnants of the landslide deposits are approximately $10 \mathrm{~m}$ high and can be observed on both sides of the channel. These deposits consist of low-stability sediment and can be easily entrained by debris flows.

Tianmo Valley is located on the northern side of the bend in the Yarlung Zangbo River and is strongly affected by new 
Table 1. Changes in glacier, snow, bare land, gully deposition and vegetation in Tianmo Valley.

\begin{tabular}{lrrrrrr}
\hline Year & $\begin{array}{r}\text { Glacier } \\
\left(\mathrm{km}^{2}\right)\end{array}$ & $\begin{array}{r}\text { Glacier } \\
(\text { eastern branch) } \\
\left(\mathrm{km}^{2}\right)\end{array}$ & $\begin{array}{r}\text { Snow } \\
\left(\mathrm{km}^{2}\right)\end{array}$ & $\begin{array}{r}\text { Bare land } \\
\left(\mathrm{km}^{2}\right)\end{array}$ & $\begin{array}{r}\text { Gully } \\
\text { deposition } \\
\left(\mathrm{km}^{2}\right)\end{array}$ & $\begin{array}{r}\text { Vegetation } \\
\left(\mathrm{km}^{2}\right)\end{array}$ \\
\hline 2000 & 1.77 & 0.16 & 2.13 & 2.80 & 0.44 & 10.46 \\
2003 & 1.71 & 0.15 & 2.44 & 2.54 & 0.44 & 10.48 \\
2006 & 1.53 & 0.12 & 2.68 & 2.44 & 0.44 & 10.55 \\
2009 & 1.45 & 0.096 & 2.81 & 3.03 & 0.47 & 9.90 \\
2013 & 1.42 & 0.088 & 1.74 & 3.83 & 0.51 & 10.17 \\
\hline
\end{tabular}

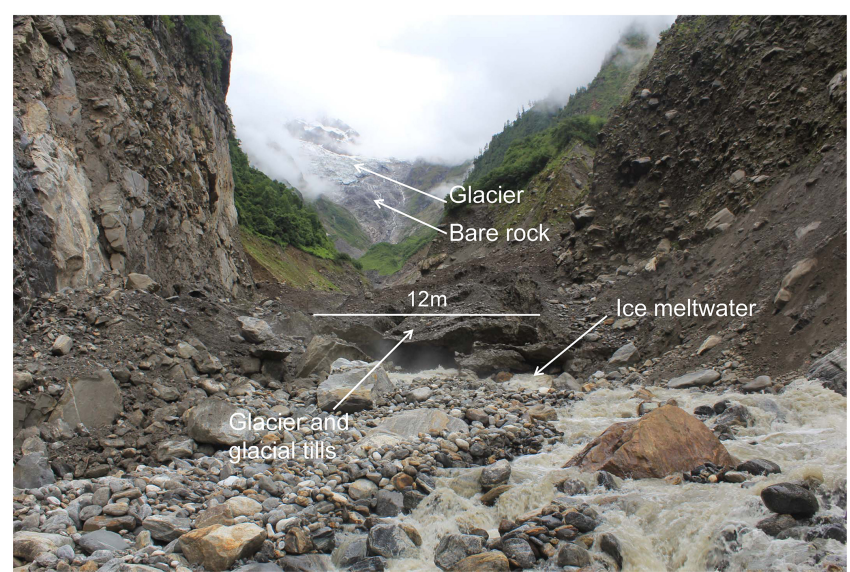

Figure 2. Overview of the valley from the channel (in 2014).

tectonic movement. An inferred normal fault vertical to the channel cuts through the valley and is only $30 \mathrm{~km}$ from the Yarlung Zangbo fault. In 1950, a rather significant earthquake $\left(M_{s}\right.$ 8.6) hit Zayu, which is only $200 \mathrm{~km}$ away, and local records reported that a large amount of rock collapsed and landslides were produced at that time. The whole valley is located in a strong ductile deformation zone and is dominated by gneissic lithology belonging to a pre-Sinian system.

\subsection{Disaster history}

According to our field interviews with local residents, there were no debris flows approximately 100 years prior to 2007 in Tianmo Valley. The channel was relatively narrow before 2007, and local people could walk across a wooden bridge to live and farm on the terrace on the western side. On the morning of 4 September 2007, a rainfall even hit this area and it ceased around 07:00. In the evening, at approximately 18:00, the local forest guard heard a loud noise coming from the upstream area and rainfall later began in the upstream area at approximately 19:00. Then, debris flows occurred in the Tianmo Channel after the second rainfall event, and they subsequently blocked the Parlung Zangbo River. It was told by local citizens that several debris flows occurred during that entire night, but we cannot separate them according to the field measurements, and approximately $1340000 \mathrm{~m}^{3}$ of sediment was transported during this event, resulting in eight missing persons as well as deaths. This debris flow event is listed as DF1 in this paper, and consists of the first debris flows and the following waves. Concurrently, debris flows occurred in the four adjacent valleys (Table 2). According to the size classification proposed by Jakob (2005), which is based on the total volume, peak discharge and inundated area, the size classes of the debris flows in the five valleys are given in Table 2.

At 11:30 on 25 July 2010, debris flows were again triggered in Tianmo Valley that traced the path of the preceding debris flow deposits and reached the other side of the Parlung Zangbo River. According to Ge et al. (2014), a solid sediment mass of approximately $500000 \mathrm{~m}^{3}$ was carried to the channel and deposited, blocking the main river (Table 1). A barrier lake was formed, and the rising water destroyed the roadbed of G318. Dozens of small-magnitude debris flows occurred in the following week. This debris flow event is listed as DF2 in this paper and it contained several waves.

Debris flows occurred again 2 months later on 6 September (The Ministry of Land and Resources P. R. C., 2010), although we could not determine the exact time sequence of the events. According to speculation, the debris flows could have occurred in the early morning before dawn when the rainfall intensity reached its maximum (Fig. 9). This theory agrees with the findings of Chen (1991), who found that periglacial debris flows historically occurred between 18:0000:00 in this area. The debris barrier in the main river was consequently increased by an additional $450000 \mathrm{~m}^{3}$, and the barrier lake was enlarged to hold $9000000 \mathrm{~m}^{3}$ of water. This debris flow event is listed as DF3 in this paper, the waves of which cannot be determined.

A field investigation revealed that a high percentage of boulders in the downstream area and glacial tills above the trough glacier are loose and are high-porosity rocks (Fig. 2); hence, they have a low density and can be easily entrained. Our particle size tests of the glacial tills and debris flow deposits indicate a low clay $(d<0.005 \mathrm{~mm})$ content, whereas the debris flow deposits contain more fine particles that are smaller than $10 \mathrm{~mm}$ (Fig. 4), suggesting that entrainment accounted for a considerable number of fine particles. 
Table 2. Basic information regarding the debris flows in Tianmo Valley and nearby valleys.

\begin{tabular}{|c|c|c|c|c|c|c|}
\hline No. & Name & Coordinates & $\begin{array}{r}\text { Basin } \\
\text { area } \\
\left(\mathrm{km}^{2}\right)\end{array}$ & $\begin{array}{r}\text { Glacier area } \\
(\text { in } 2006) \\
\left(\mathrm{km}^{2}\right)\end{array}$ & Date & $\begin{array}{l}\text { Size } \\
\text { class }\end{array}$ \\
\hline 1 & Tianmo Valley & $\begin{array}{l}29^{\circ} 59^{\prime} \mathrm{N} \\
95^{\circ} 19^{\prime} \mathrm{E}\end{array}$ & 17.74 & 1.53 & $\begin{array}{l}4 \text { Sep } 2007 \\
\text { 25 Jul } 2010 \\
6 \text { Sep } 2010\end{array}$ & $\begin{array}{l}6 \\
5 \\
5\end{array}$ \\
\hline 2 & Kangbu Valley & $\begin{array}{l}30^{\circ} 16^{\prime} \mathrm{N} \\
94^{\circ} 48^{\prime} \mathrm{E}\end{array}$ & 48.7 & 1.06 & 4 Sep 2007 & 3 \\
\hline 3 & Xuewa Valley & $\begin{array}{l}29^{\circ} 57^{\prime} \mathrm{N} \\
95^{\circ} 23^{\prime} \mathrm{E}\end{array}$ & 33.22 & 0.95 & 4 Sep 2007 & 2 \\
\hline 4 & Baka Valley & $\begin{array}{l}29^{\circ} 53^{\prime} \mathrm{N} \\
95^{\circ} 33^{\prime} \mathrm{E}\end{array}$ & 22.15 & 2.46 & 7 Sep 2007 & 3 \\
\hline 5 & Jiaqing Valley & $\begin{array}{l}30^{\circ} 16^{\prime} \mathrm{N} \\
94^{\circ} 49^{\prime} \mathrm{E}\end{array}$ & 15.51 & 1.12 & 9 Sep 2007 & 3 \\
\hline
\end{tabular}

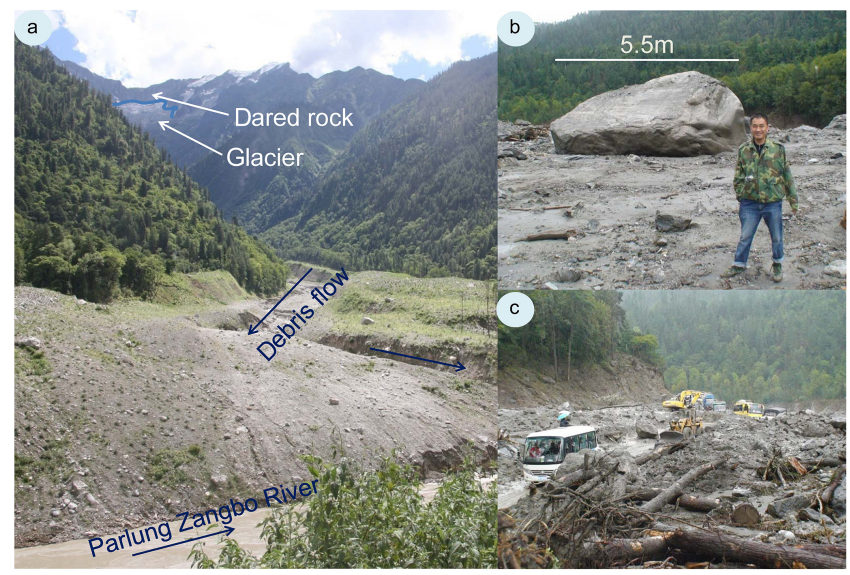

Figure 3. DF1 in 2007 (a) Overview of the Tianmo debris flows from the downstream area; (b, c) Boulder and debris flow deposits on the northern side of the Parlung Zangbo River).

\subsection{Meteorological data}

The study area is located in a high alpine area where the economy is relatively undeveloped and few meteorological stations exist. Before 2011, the Bomi meteorological station (established in 1955) was the only station in the area. It is located $54 \mathrm{~km}$ from Tianmo Valley at an elevation of $2730 \mathrm{~m}$, and other stations were located more than $200 \mathrm{~km}$ away.

The Tibetan Plateau is a massive terrace that obstructs the Indian monsoon, causing it to travel through the Yarlung Zangbo Canyon and its tributaries. As the Indian monsoon is transported to higher altitudes, a rainfall gradient emerges in the Parlung Zangbo Basin. However, according to the rainfall data from the area, rainfall often exhibits a similar intensity to that of the long-term rainfall process from Guxiang to Songzong, which suggests that a large rainfall gradient does

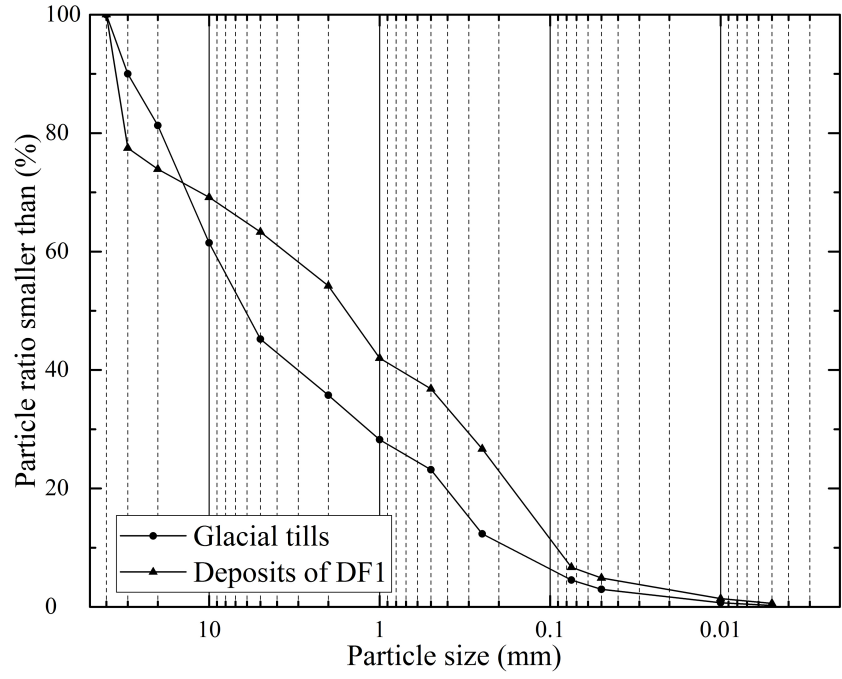

Figure 4. Particle size distributions of the glacial tills and debris flow deposits.

not exist between Tianmo Valley and Bomi meteorological station; therefore, the rainfall data from Bomi meteorological station could be used in our study. To conduct additional studies, another meteorological station was built in 2011 near Tianmo Valley.

It has been established that the air temperature decreases with altitude; therefore, the air temperature in the source area of Tianmo Valley is lower than that in Bomi County. According to the research by $\mathrm{Li}$ and $\mathrm{Xie}$ (2006), the air temperature decreases at a rate of $0.46-0.69^{\circ} \mathrm{C} / 100 \mathrm{~m}$ over the entire Tibetan Plateau, and the rate in the study area is $0.54^{\circ} \mathrm{C} / 100 \mathrm{~m}$. Because the glacier and permafrost in the source area have planar distributions, the air temperature at the geometric cen- 


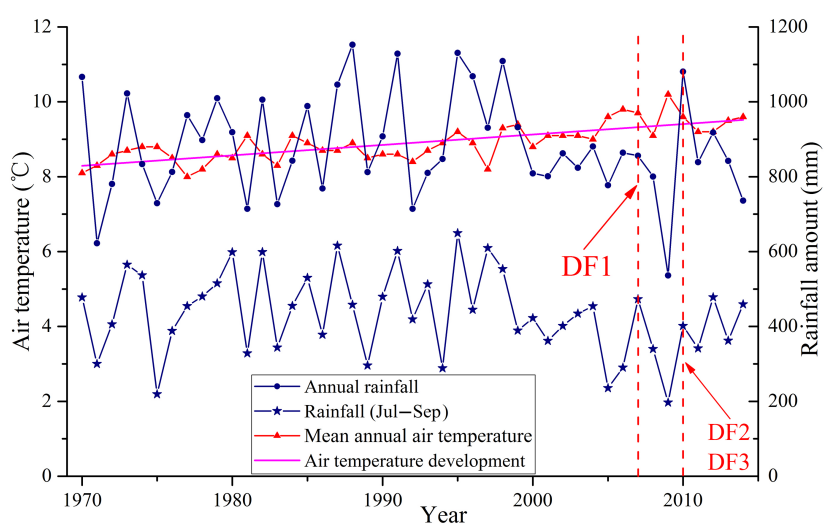

Figure 5. Variation in the mean annual air temperature and rainfall at Bomi from 1970 to 2014.

tre of the glacier and permafrost can be used to analyse the temperature process.

\section{Analysis and results}

\subsection{Air temperature and rainfall changes}

The mean annual air temperature is generally used to reflect the trends of glacier change (Yang et al., 2016). We collected mean annual air temperature and annual rainfall data from 1970 to 2014 from the Bomi meteorological station (Fig. 5). The records showed that the mean air temperature has increased by approximately $1.5^{\circ} \mathrm{C}$ over the past 45 years at a rate of $0.033^{\circ} \mathrm{Ca}^{-1}$. This air temperature increase was particularly rapid between 2005 and 2007 at approximately $0.7^{\circ} \mathrm{C} / 3 \mathrm{a}$, which is seven times the average value over the past 45 years. However, the annual rainfall from 2000 to 2010 was low and estimated at $828.2 \mathrm{~mm}$ per year. From 2000 to 2004, the rainfall during summer (July to September) accounted for approximately $50 \%$ of the total annual rainfall; however, only $32 \%$ of the rainfall occurred in the summer of 2005-2006, even though the annual rainfall exhibited a similar trend. In 2007, rainfall in the summer and the entire year returned to the mean rainfall state.

Figure 5 shows similar air temperature and rainfall trends before DF2 and DF3. The air temperature increased in 2009 and reached $10.2^{\circ} \mathrm{C}$ which is the maximum of the past 45 years; however, the annual rainfall went down to only $65 \%$ of the average amount, and the summer rainfall reached a minimum value. In 2010, rainfall was abundant, and the annual rainfall increased to $1080.6 \mathrm{~mm}$, which is approximately $30 \%$ more than the average value and close to the maximum.

The following common traits can be identified by comparing the annual meteorological conditions of DF1, DF2 and DF3: (1) 1 or 2 years before the debris flows, the mean annual temperature increased and the annual rainfall and summer rainfall decreased. Additionally, the climate was in a "hot- dry" state. (2) As the temperature gradually decreased, the annual rainfall returned to normal or increased, and a "hotwet" climate state contributed to debris flow initiation ( $\mathrm{Lu}$ and $\mathrm{Li}, 1989$ ).

\subsection{Changing of glacier in Tianmo Valley}

In our study, remote images were collected to analyse the glacier changes in the source area in recent years. To eliminate the effect of snow cover, images were taken in the thawing seasons when snow cover is limited, enabling easy detection of glaciers and snow. Moreover, an image taken on a bright, cloudless day is still needed to show the watershed clearly; however, a difficult case is encountered when the rainy season begins during the thawing season, as the atmosphere is often covered by thick clouds. Furthermore, to illustrate glacier retreat and its impact on debris flows properly, the images should be within similar time intervals, such as 3 years, before and after debris flow events. High-resolution images are rare, and we could only collect one SPOT image (taken by the Systeme Probatoired' Observation de la Terre satellite with a spatial resolution of $5 \mathrm{~m}$ ) in 2008. To achieve image consistency, we collected 5 TM images taken on 17 September 2000, 24 July 2003, 21 September 2006, 24 September 2009 and 4 August 2013.

Based on the $5 \mathrm{TM}$ images, we classified the area as glacier, snow, bare land, gully deposit and vegetation in time series (Fig. 6), and the area of each is given in Table 1. Figure 6 shows that deglaciation occurred in Tianmo Valley; notably, the eastern branch has experienced considerable deglaciation. To clearly show the rapid rate of glacial retreat in the entire basin and eastern branch, a graph of retreat was plotted, as shown in Fig. 7.

Figure 7 shows that the glacier in Tianmo Valley shrank from 2000 to 2013, with variable rates of glacier retreat. In 2000-2003, 2003-2006, 2006-2009 and 2009-2013, the glacier retreat rates in Tianmo Valley were $0.02,0.06,0.027$ and $0.0075 \mathrm{~km}^{2} \mathrm{a}^{-1}$, respectively, and those of the eastern branch were $0.0033,0.01,0.008$ and $0.002 \mathrm{~km}^{2} \mathrm{a}^{-1}$, respectively. According to the figure, the largest glacier retreat rate was observed in 2003-2006, followed by that in 2006-2009. The glacier area at the beginning should be noted to assess the rate of change of the glacier. The glacier retreat rate can be normalised, and the relative glacier retreat rate can be calculated based on this change in area.

The relative glacier retreat rates were $11.30 \times 10^{-3}$, $35.09 \times 10^{-3}, 17.43 \times 10^{-3}$ and $5.17 \times 10^{-3} \mathrm{~km}^{2} \mathrm{a}^{-1} \mathrm{~km}^{-2}$ in 2000-2003, 2003-2006, 2006-2009 and 20092013, respectively, and the corresponding values were $20.83 \times 10^{-3}, \quad 66.67 \times 10^{-3}, \quad 66.67 \times 10^{-3}$ and $20.83 \times 10^{-3} \mathrm{~km}^{2} \mathrm{a}^{-1} \mathrm{~km}^{-2}$ for the eastern branch. The relative glacier retreat rate of the eastern branch decreased sharply between 2000-2013.

In this study, TM images over 3-year intervals were applied to obtain the mean glacier retreat rate. As glacier re- 


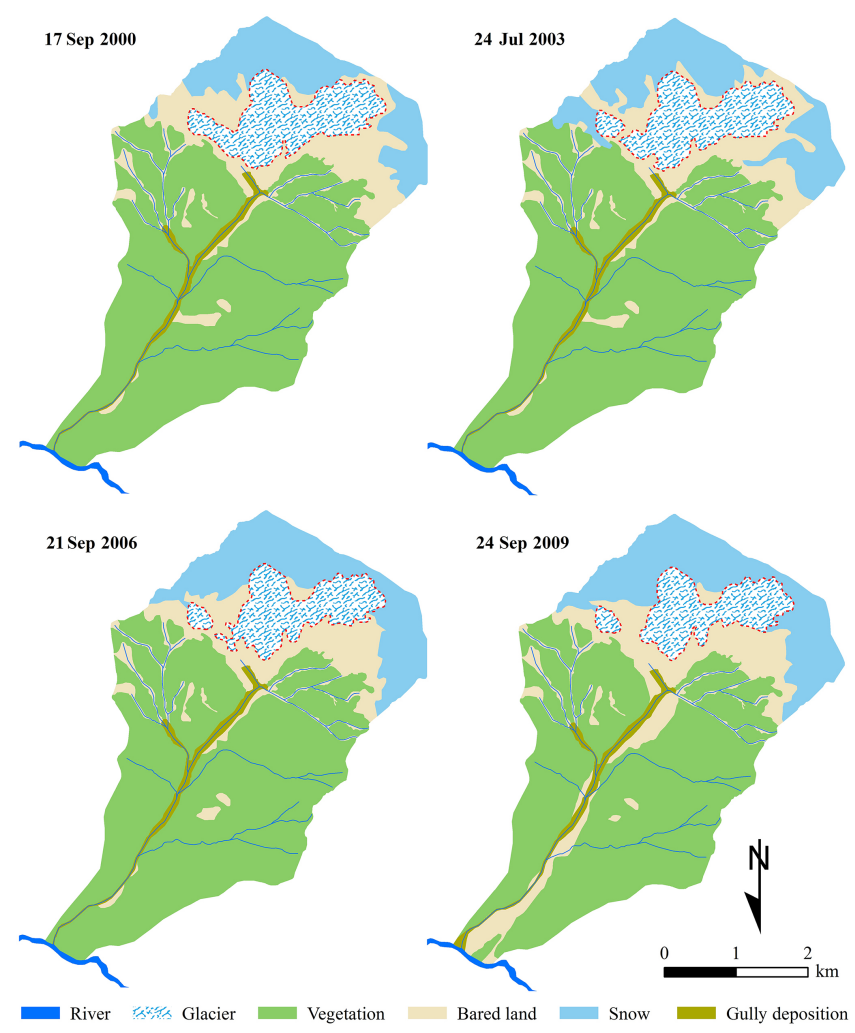

Figure 6. Distribution and changes in glacier, snow, bare land, gully deposition and vegetation in Tianmo Valley.

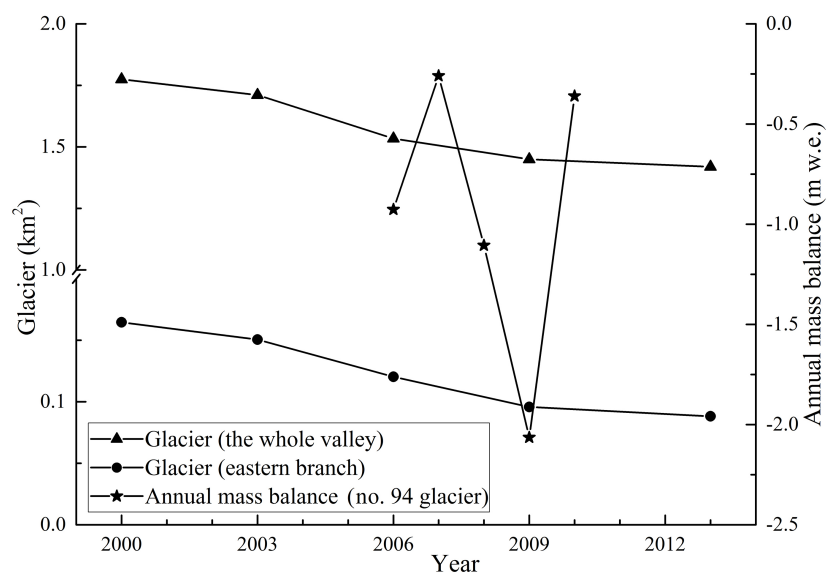

Figure 7. Changes in glacier over time and the measured annual mass balance of the Parlung No. 94 Glacier (mass balance was edited from Yang et al., 2016).

treat rate in the 3 years could be either high or low, field measurements of the nearby glacier were used to show the glacier retreat condition before debris flows occurred. Yang et al. (2016) conducted field measurements of the No. 94 Glacier in the Parlung Zangbo Basin since 2006, and the field measurements suggest it had a negative balance from 2006-2010 (Fig. 7). The negative balance reached a maxi-

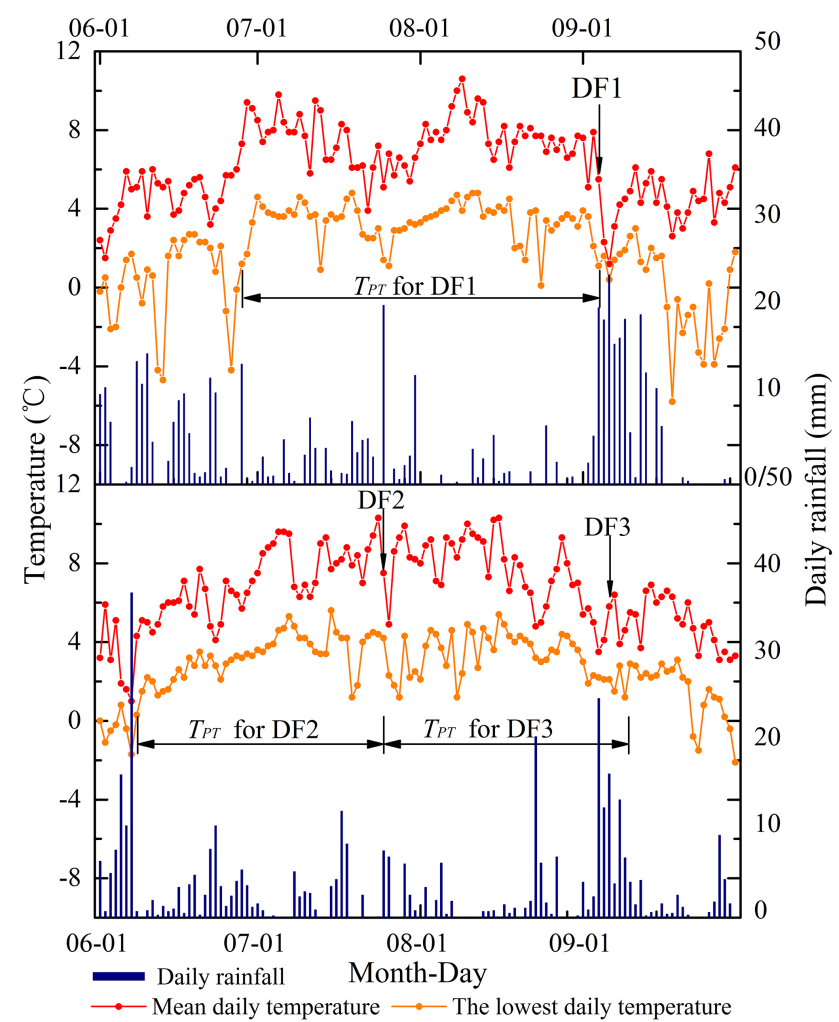

Figure 8. Air temperature and rainfall before and after DF1, DF2 and DF3.

mum level in 2009, followed by 2008 and 2006, indicating rapid deglaciation in these 3 years.

When we combined the results of the TM image analysis and field measurements of the No. 94 Glacier, we observed that the glacier in Tianmo Valley experienced the most rapid deglaciation prior to debris flows in 2006, 2008 and 2009, which coincided with an increase in the mean annual air temperature (Fig. 5). Moreover, the maximum glacier retreat in 2009 was potentially related to the decline in snowfall in the preceding winter and early spring.

\subsection{Antecedent air temperature and rainfall}

The air temperature in the source area can be obtained based on a vertical rate of decline $\left(0.54^{\circ} \mathrm{C} / 100 \mathrm{~m}\right)$. Based on this method, the air temperature in the source area was $9.8^{\circ} \mathrm{C}$ lower than that at the Bomi meteorological station. We collected the lowest temperature, the mean temperature and daily rainfall from June to September in 2007 and 2010 (Fig. 8).

Figure 8 shows that the lowest air temperature was below 0 at the end of June 2007. At the beginning of July, the air temperature started to rise quickly, which continued until early September when DF1 occurred. This trend suggests that the high air temperatures in July and August contributed to DF1. 
Additionally, the air temperature was high from early July to late August, and another high air temperature period was observed in early September. When DF2 occurred in late July, the air temperature had reached the maximum for that year, which suggests that the air temperature in early and mid-July was responsible for DF2. After DF2 occurred, the air temperature in August varied towards the conditions that caused DF3.

Antecedent air temperature fluctuations include the air temperature and the duration of variations. The air temperatures and durations before debris flows are variable and difficult to evaluate. The accumulation of positive air temperature is often used to analyse the effect of air temperature on glacier melting (Rango and Martinec, 1995) and can be expressed as follows:

$T_{\mathrm{PT}}=\sum_{i=-n}^{0} T_{i}\left(T_{i}>0\right)$,

where $T_{\mathrm{PT}}$ is positive air temperature accumulation $\left({ }^{\circ} \mathrm{C}\right)$ and $T_{i}$ is the average daily air temperature (only $T_{i}>0$ is included).

Because air temperature is successive, it is difficult to determine the beginning of positive air temperature accumulation. Glacial tills can decrease the heat that penetrates into them, and the low air temperature is only observed in the upper thin layer. Moreover, freeze-thaw cycles exist when the lowest air temperature is less than $0{ }^{\circ} \mathrm{C}$. From this perspective, the beginning of positive air temperature accumulation is defined as the time at which the lowest air temperature exceeds $0^{\circ} \mathrm{C}$ for two or three successive days or since the last debris flow.

Based on the above method, we can deduce that positive air temperature accumulation began when the lowest air temperature exceeded $0^{\circ} \mathrm{C}$ for several successive days beginning on 28 June 2007, 9 June 2010, and 26 July 2010, which correspond to DF1, DF2 and DF3, respectively. The duration and $T_{\mathrm{PT}}$ were calculated for each debris flow event. The results were 69 days and $517.9^{\circ} \mathrm{C}, 47$ days and $332.1^{\circ} \mathrm{C}$ and 42 days and $320.4^{\circ} \mathrm{C}$ (Fig. 8) for DF1, DF2 and DF3, respectively. The results showed that $T_{\mathrm{PT}}$ for DF1 was much larger than the other two $T_{\mathrm{PT}}$ values, which coincides with the fact that there were no debris flows in the last few dozens of years, and that extraordinary external forces such as large $T_{\mathrm{PT}}$ are required to disrupt the long-term balance.

\subsection{Triggering conditions}

Rainfall over a short period can trigger debris flows but it cannot be triggered by a sole abrupt increase in air temperature as the continuous and limited nature of air temperature; instead, air temperature over a longer term should be included. In our analysis, the rainfall over the 3 days preceding a debris flow event is given in Fig. 9.

Before DF1, the air temperature was high, which continued through July and August. Notably, the $T_{\mathrm{PT}}$ reached

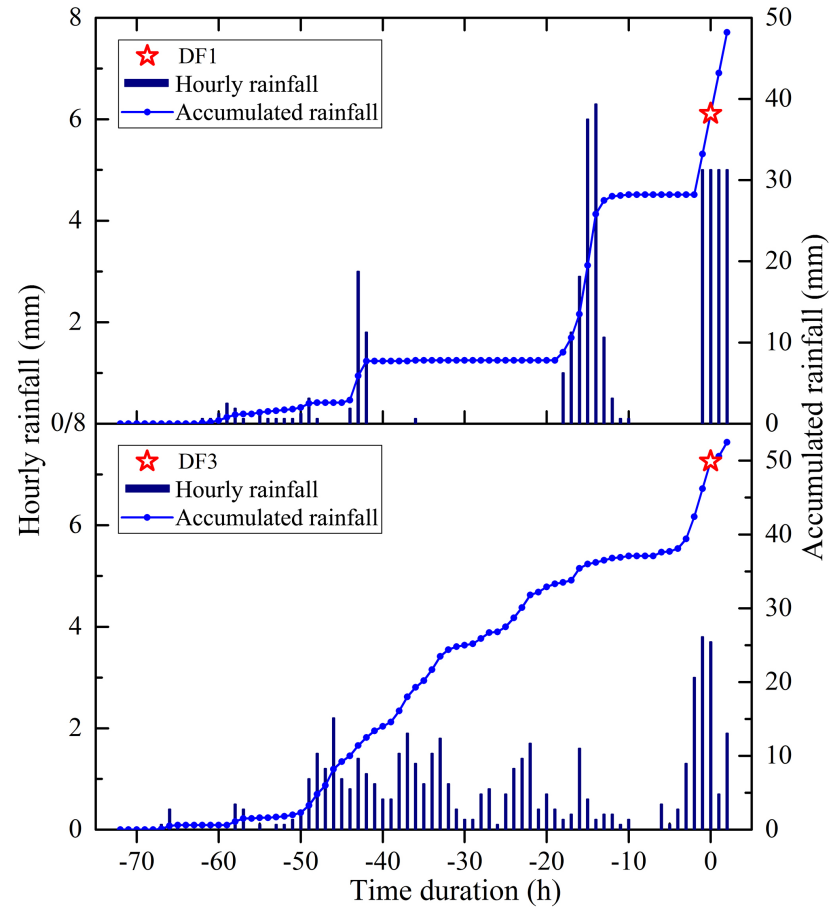

Figure 9. Variations in rainfall accumulation prior to DF1 and DF3 (no rainfall before DF2).

$517.9^{\circ} \mathrm{C}$. According to the local forest guard, an isolated convective storm occurred prior to DF1, although no rainfall was recorded at the Bomi meteorological station or in the downstream area at that time. In Fig. 9, as the rainfall right before DF1 occurred was not recorded by the Bomi metrological station, we added approximately $5 \mathrm{~mm} \mathrm{~h}^{-1}$ of rainfall intensity (according to the description provided by the forest guard) before DF1 to account for the storm, which might not reflect the real rainfall process. We can therefore conclude that this isolated convective storm initiated DF1, while the long-term high air temperature trend paved the way for DF1. Regarding a large deglaciated area, several other periglacial debris flows simultaneously occurred near Tianmo Valley (Deng et al., 2013), which suggests the advantageous meteorological conditions for debris flow initiation.

DF2 occurred when the air temperature reached a peak in 2010. The thaw season began in the middle of June, and $T_{\mathrm{PT}}$ reached $332.1^{\circ} \mathrm{C}$. On 24 July, 1 day before DF2, the air temperature reached a maximum value for that year. No rainfall event hit this area preceding DF2 according to the record of Bomi meteorological station, and the local citizens also observed no rain. The trigger of DF2 was likely the continuous percolation of meltwater due to the long-term increase in air temperature.

According to field interviews, several debris flows of small magnitude occurred before DF3. The air temperature decreased in late August but increased to another high value before $\mathrm{DF} 3$, and the $T_{\mathrm{PT}}$ reached $320.4^{\circ} \mathrm{C}$. Rainfall began 


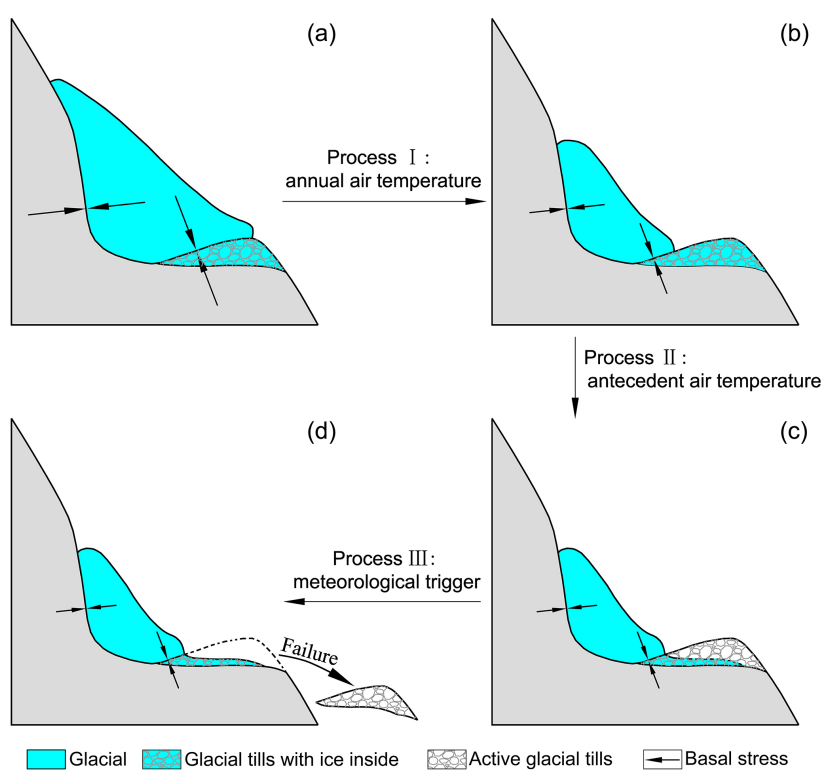

Figure 10. Changes in glacier and frozen glacial till before periglacial debris flow initiation (a) glacial-covered glacial tills, (b) uncovered and frozen glacial tills, (c) active glacial tills, (d) failure of glacial tills).

2 days prior to DF3 and lasted the entire day before DF3. According to the rainfall trend at the Bomi meteorological station, the rapid increase in rainfall intensity started $4 \mathrm{~h}$ before DF3 and reached $3.8 \mathrm{~mm} \mathrm{~h}^{-1}$, which was responsible for the initiation of DF3.

\section{Discussion}

In this study, we found that the triggering factors of the three debris flows were high air temperature and rainfall for DF1, high air temperature for DF2 and storm for DF3. When we analysed the dates and triggers of these events, various questions should be settled first: (1) why did debris flows not occur in 2006 or 2009 when deglaciation reached its peak and more ice meltwater was present; (2) why did DF1 and DF3 occur in September when the air temperature and volume of ice meltwater were decreasing; and (3) why were there no large-scale debris flows triggered by previous heavy storms? Based on our results, we believe that the impact of the water source on the magnitude and frequency of debris flows is relatively small, or more debris flows would form during the early larger storm; instead, the sediment source, including the associated magnitude and activity, may be the predominant control, as reported by Jakob et al. (2005), who noted that channel recharge is a prerequisite for debris flows. However, in most situations, we cannot reach the source area to detect the soil source, and high-tech remote sensing can only distinguish the boundary of the soil source. In the periglacial area where glacial till is often covered by glacier or everlast- ing snow, a change in the soil source would be highly difficult to detect. In this study, we combine the meteorological conditions and literature reports to discuss the likely variations in glacial tills before debris flows.

\subsection{Annual variations in glacial till}

Climate warming is a global trend (IPCC, 2013), and the Tibetan Plateau, as the third pole, is no exception to climate change. According to our statistics, the air temperature in Bomi County has increased by $1.5^{\circ} \mathrm{C}$ over the past 45 years (1970-2014). Glacier retreat induced by climate warming has been widely accepted, and recent research suggests that the weaker Indian monsoon could be another reason for such retreat (Yao et al., 2012). Glaciers are always located in concave ground areas and cover large volumes of glacial tills. Glacial pressure can generate normal stress vertical to the slope, which can strengthen the slope stability. The effect of glaciers on slope stability is called glacial debuttressing (Cossart et al., 2008). As deglaciation continues, the result could lead to the exposure of the frozen glacial tills (Fig. 10a to b) and smaller glacial debuttressing.

The retreats of glaciers and glacial tills due to climate warming are quite different. The newly formed bare glacial till is frozen with a high ice content. The cohesion of the ice particles creates a bare glacial till with high shearing strength and stability. Deglaciation is accompanied by the melting of internal ice particles, which can greatly enhance the activity. This process first occurred at the surface layer of glacial till, followed the layers below, resulting in the enlargement of active debris. As the debris obstruct heat fluxes from penetrating into the layer below, so the melting rate of internal ice particles is quite a bit slower than that of glacial retreat (Takeuchi et al., 2000), resulting in a strong heat gradient at the surface while limited in deep layers, which means the activity of the debris decline with depth and long-term high air temperature is required to enhance the activity in a deeper layer. As the ablation rates is quite low, only the surface layer is highly active and the sediment is relatively limited. Therefore, no debris flows of large magnitude could have occurred in 2006 and 2009 when glacier retreat reached a maximum while the active glacial till is restricted to the surface layer.

\subsection{Variation in glacial till on antecedent days}

After the long, cold winter, glacial tills become frozen. If a regressive glacier does not recover in the winter, glacial tills are covered by snow. As the air temperature increases again, the surface snow melts first, followed by the internal ice particles. The thawing of internal ice particles induces a series of changes in the glacial till, which include the following: (1) the thawing will break the bonds of ice particles and increase the instability between ice cracks (Ryzhkin and Petrenko, 1997; Davies et al., 2001); (2) the sharp air temperature fluctuations in high alpine, mountainous areas in- 
duce a repeated cycle of expansion and contraction in the glacial till that can destroy the mass structure to some extent; (3) the seepage of ice meltwater can transport fine-grained sediments that were formerly frozen in the ice matrix (Rist, 2007); and (4) the ice meltwater can result in a higher water content and pore water pressure (Bommer et al., 2012). These changes in glacial till can sharply decrease the soil strength, shifting to an active mass from an uncovered and frozen moraine (Fig. 10b to c). Because heat conduction in glacial till is relatively slow, this process may last for a very long time and require a high antecedent air temperature.

Heat conduction via the percolation of rainfall and ice meltwater can amplify the depth of active glacial till (Gruber and Haeberli, 2007), whereas covering the surface glacial till can hinder a heat flux from penetrating into the deep layers (Noetzli et al., 2007). At a low air temperature, the heat flux should be constrained to the surface layer, and a large heat gradient due to a high air temperature would contribute much more to the heat flux and ice melt in the deep mass. Thus, the long-term effect of a high air temperature can amplify the active glacial till (Noetzli et al., 2007; Åkerman and Johansson, 2008), under which lies frozen glacial till with a high ice content. The activity of glacial till varies with depth from high at the surface to low in the deep layers, and landslide failure can take place on glacial till slopes in a retrogressive manner, coinciding with long-term air temperature fluctuations, as active glacial till is relatively limited in deglaciated areas.

\subsection{Failure of glacial till}

Different factors can lead to glacial till failure. Active glacial till slopes with low strength are usually vulnerable, and their failure can occur when the air temperature is above $0{ }^{\circ} \mathrm{C}$ (Arenson and Springman, 2005). Rainfall or ice melt water induced by air temperature can trigger a failure (Fig. 10cd). This type of event is called a shallow landslide, and the failure mechanism lies in the ablation of internal ice particles and the percolation of meltwater, which can initially decrease the soil strength (Arenson and Springman, 2005; Decaulne et al., 2005). Later, the subsequent rapid percolation of ice meltwater or heavy rainfall can saturate the debris, decrease soil suction and shearing strength, and form seepage flows that can trigger the shallow landslide failure (Springman et al., 2003; Decaulne and Sæmundsson, 2007; Chiarle et al., 2007). Whether the failure can induce debris flows is still dependent on its ability to entrain the debris layer as the flow moves through the channel.

Another type of failure might take place when peaked runoff flows over and entrains debris deposits in the charged channel and reach a critical discharge (Berti and Simoni, 2005; Gregoretti and Dalla Fontana, 2008; Kean et al., 2012, 2013; Takahashi, 2014; Rengers et al., 2016; Gregoretti et al., 2016), which is more determined by channel bed slope and grain size of debris (Tognacca et al., 2000; Gregoretti, 2000; Theule et al., 2012; Hurlimann et al., 2014; Degetto et al., 2015). This type of channelised run-off could be a combination of three factors: rainfall, melting ice or the overflow that forms when a glacier collapses downward into a water pool. The mechanism of this process lies in the hydrodynamic forces exerted on the surface elements of debris layers and surpassing sediment resistance (Gregoretti and Dalla Fontana, 2008; Recking et al., 2009; Prancevic et al., 2014). The concentration of run-off in the channel bottom causes the erosion of the debris surface layer, forming a solid-liquid current at first, then extends to the layers below with whole or partial mobilisation and debris flows were generated (Gregoretti and Dalla Fontana, 2008). Therefore, debris flows initiated by landslide failure caused by seepage flow or channelised run-off that entrain sediments in the periglacial area are similar to the mechanism of debris flow initiation in non-glacier areas (Iverson et al., 1997; Springman et al., 2003; Sassa and Wang, 2005; Gregoretti and Dalla Fontana, 2008; Kean et al., 2013), while the difference lies in the activity of debris and the source of water. In the European Alps, periglacial debris flows are mainly provoked by rainfall, which is also related to air temperature fluxes (Stoffel et al., 2011). Additionally, the values of rainfall and air temperature required to trigger debris flows could be inversely correlated. Air temperature increases can cause melting and water run-off; thus, the amount of rainfall required to create percolation flows or critical discharge to trigger a debris flow would be much lower. In addition, the intensity and duration of the required rainfall may require other preconditions, such as those associated with the distributions of glaciers and frozen glacial tills and the terrain of the source area, to enhance the debris flow (Lewkowicz and Harris, 2005).

The three debris flow events were associated with similar annual meteorological conditions, except that the positive air temperature accumulation prior to DF1 was the largest. DF1 occurred at the end of a prolonged period of high air temperature, prior to this, there were instances of small failures but no large-scale debris flows. On 25 July 2007, the daily rainfall reached $20.7 \mathrm{~mm}$, but no debris flows were generated because the active glacial till is restricted in the shallow surface layer after a short period of air temperature increase.

In 2010, the largest daily rainfall amount occurred on 7 June, accounting for $37.5 \mathrm{~mm}$, at the beginning of an air temperature increase when the glacial till was frozen with low activity. The lack of glacial till with high activity was the likely cause of the absence of debris flows. A similar situation could be found on 23 August when the daily rainfall was $20.3 \mathrm{~mm}$ and the positive air temperature accumulation had been low since DF2, which had produced quite a limited active glacial till. Besides, a low and positive air temperature was observed prior to 6 September, when DF3 occurred and the boundary of active glacial till had been enlarged; moreover, the high rainfall intensity could have supplemented this lack of prolonged high air temperature and triggered debris flows. 


\section{Conclusion}

Climate changes have serious effects in high mountainous areas, and the mass movement of sediments such as periglacial debris flows has become increasingly frequent. Prolonged increases in the mean annual air temperature are regarded as very favourable for periglacial debris flows. In particular, the annual hot-dry weather conditions 1 or 2 years prior were responsible for three debris flow events in Tianmo Valley. Debris flows are generally not initiated in the year when the mean annual air temperature spikes, as the melting of internal ice particles lags behind the rate of glacial retreat, resulting from a prolonged increase in air temperature.

Glacial till is unlimited in deglaciated areas, and its activity relies on glacial retreat and internal ice particle melting. Glacial till changes induced by increased air temperature are the first steps in forming periglacial debris flows compared to storm-induced debris flows in non-glacier areas. Glacial tills require a four-phase process prior to debris flow occurrence. In this process, the variation in air temperature drives the glacial till change, including causing glacier recession, producing bare glacial till and enhancing the glacial till activity. Debris flows can occur when a sufficient amount of active glacial till exists and rainfall-induced seepage or runoff is more likely to generate debris flows.

It is difficult to observe glacial till changes in source areas of debris flows, and the analysis of the phase conversion of glacial till in this study is based on the triggering conditions and other literature findings. Indeed, the meteorological conditions, such as the antecedent air temperature and meteorological triggers that drive the phase conversion, are partly coupled and difficult to distinguish.

Data availability. Meteorological data is downloaded from http://data.cma.cn/. The meteorological data and the particle size distribution data are available online (https: //www.researchgate.net/publication/314212885_Tianmo-annual_ rainfall_and_termparature, Deng et al., 2017). The remote sensing image is available from the USGS (http://earthexplorer.usgs.gov/) and the serial number of the 5 remote-sensing images is and LT51350392000261BKT00, LT51350392003205BJC00, LT51350392006261BJC00, LT51350392009269KHC00 and LC81350392013216LGN00, respectively in 2000, 2003, 2006, 2009 and 2013. Any other processed data files are also available on request from the first or corresponding author.

Competing interests. The authors declare that they have no conflict of interest.

Acknowledgements. This research was supported by the National Natural Science Foundation of China (grant no. 41190084, 41402283 and 41371038) and the "135" project of IMHE, CAS. We wish to acknowledge the editors of the Natural Hazards and
Earth System Science Editorial Office and the reviewers for their constructive comments, which helped us improve the contents and presentation of the manuscript.

Edited by: P. Tarolli

Reviewed by: F. Comiti and one anonymous referee

\section{References}

Åkerman, H. J. and Johansson, M.: Thawing permafrost and thicker active layers in sub-Arctic Sweden, Permafrost Periglac., 19, 279-292, 2008.

Arenson, L. U. and Springman, S. M.: Mathematical descriptions for the behaviour of ice-rich frozen soils at temperatures close to $0{ }^{\circ} \mathrm{C}$, Can. Geotech. J., 42, 431-442, 2005.

Berti, M. and Simoni, A.: Experimental evidences and numerical modelling of debris flow initiated by channel runoff, Landslides, 2, 171-182, 2005.

Bommer, C., Fitze, P., and Schneider, H.: Thaw-consolidation effects on the stability of Alpine talus slopes in permafrost, Permafrost Periglac., 23, 267-276, 2012.

Chen, N. S., Zhou, H. B., and Hu, G. S.: Development rules of debris flow under the influence of climate change in Nyingchi, Adv. Clim. Change Res., 7, 412-417, 2011 (in Chinese).

Chen, R.: Initiation and the Critical Condition of Glacial Debris Flow, Master thesis, Institute of Mountain Hazards and Environment, Chinese Academic of Sciences, p. 19, 1991.

Cheng, Z. L., Wu, J. S., and Geng, X.: Debris flow dam formation in southeast Tibet, J. Mt Sci., 2, 155-163, 2005.

Chiarle, M., Iannotti, S., Mortara, G., and Deline, P.: Recent debris flow occurrences associated with glaciers in the Alps, Global Planet. Change, 56, 123-136, 2007.

Cossart, E., Braucher, R., Fort, M., Bourlès, D. L., and Carcaillet, $\mathrm{J}$.: Slope instability in relation to glacial debuttressing in alpine areas (Upper Durance catchment, southeastern France): evidence from field data and ${ }^{10} \mathrm{Be}$ cosmic ray exposure ages, Geomorphology, 95, 3-26, 2008.

Cruden, D. M. and Hu, X. Q.: Exhaustion and steady state models for predicting landslide hazards in the Canadian Rocky mountains, Geomorphology, 8, 279-285, 1993.

Davies, M. C. R., Hamza, O., and Harris, C.: The effect of rise in mean annual temperature on the stability of rock slopes containing ice-filled discontinuities, Permafrost Periglac., 12, 137-144, 2001.

Decaulne, A. and Sæmundsson, T.: Spatial and temporal diversity for debris-flow meteorological control in subarctic oceanic periglacial environments in Iceland, Earth Surf. Proc. Land., 32, 1971-1983, 2007.

Decaulne, A., Sæmundsson, T., and Petursson, O.: Debris flows triggered by rapid snowmelt in the Gleidarhjalli area, northwestern Iceland, Geogr. Ann., 87, 487-500, 2005.

Degetto, M., Gregoretti, C., and Bernard, M.: Comparative analysis of the differences between using Lidar contour-based DEMs for hydrological modeling of runoff generating debris flows in the Dolomites, Front. Earth Sci., 3, 1-15, 2015.

Deng, M. F., Chen, N. S., Ding, H. T., and Zhou, C. C.: The hydrothermal condition of 2007 group-occurring debris flows and 
its triggering mechanism in Southeast Tibet, J. Nat. Dis., 22, 128-134, 2013 (in Chinese).

Deng, M. F., Chen, N. S., and Liu, M.: Tianmo-annual rainfall and temperature, available at: https://www.researchgate. net/publication/314212885_Tianmo-annual_rainfall_and_ termparature, 2017.

Evans, S. G., Tutubalina, O. V., Drobyshev, V. N., Chernomorets, S. S., McDougall, S., Petrakov, D. A., and Hungr, O.: Catastrophic detachment and high-velocity long-runout flow of Kolka Glacier, Caucasus Mountains, Russia in 2002, Geomorphology, 105, 314-321, 2009.

Fischer, L., Purves, R. S., Huggel, C., Noetzli, J., and Haeberli, W.: On the influence of topographic, geological and cryospheric factors on rock avalanches and rockfalls in highmountain areas, Nat. Hazards Earth Syst. Sci., 12, 241-254, https://doi.org/10.5194/nhess-12-241-2012, 2012.

Ge, Y. G., Cui, P., Su, F. H., Zhang, J. Q., and Chen, X. Z.: Case history of the disastrous debris flows of Tianmo watershed in Bomi County, Tibet, China: some mitigation suggestions, J. Mt. Sci., 11, 1253-1265, 2014.

Gregoretti, C.: The initiation of debris flow at high slopes: experimental results, J. Hydraul. Res., 38, 83-88, 2000.

Gregoretti, C. and Dalla Fontana, G..: The triggering of debris flow due to channel-bed failure in some alpine headwater basins of the Dolomites: analyses of critical runoff, Hydrol. Process., 22, 2248-2263, 2008.

Gregoretti, C., Degetto, M., Bernard, M., Crucil, G., Pimazzoni, A., De Vido G., Berti, M., Simoni, A., and Lanzoni, S.: Runoff of small rocky headwater catchments: Field observations and hydrological modeling, Water Resour. Res., 52, 8138-8158, 2016.

Gruber, S. and Haeberli, W.: Permafrost in steep bedrock slopes and its temperature-related destabilization following climate change, J. Geophys. Res., 112, F02S18, https://doi.org/10.1029/2006JF000547, 2007.

Guzzetti, F., Peruccacci, S., Rossi, M., and Stark, C. P.: The rainfall intensity-duration control of shallow landslides and debris flows: an update, Landslides, 5, 3-17, 2008.

Harris, C., Arenson, L. U., Christiansen, H. H., Etzelmüller, B., Frauenfelder, R., Gruber, S., Haeberli, W., Hauck, C., Hölzle, M., Humlum, O., Isaksen, K., Kääb, A., Kern-Lütschg, M. A., Lehning, M., Matsuoka, N., Murton, J. B., Nötzli, J., Phillips, M., Ross, N., Seppälä, M., Springman, S. M., and Vonder Mühll, D.: Permafrost and climate in Europe: monitoring and modelling thermal, geomorphological and geotechnical responses, EarthSci. Rev., 92, 117-171, 2009.

Hurlimann, M., Abanco, C., Moya, J., and Vilajosana, I.: Results and experiences gathered at the Rebaixader debris-flow monitoring site, Central Pyrenees, Spain, Landslides, 11, 939-953, 2014.

Intergovernmental Panel of Climate Change (IPCC): Summary for Policymakers: Working Group I Contribution to the IPCC Fifth Assessment Report Climate Change 2013: The Physical Science Basis, Cambridge University Press, Cambridge, UK, 2013.

Iverson, R. M., Reid, M. E., and LaHusen, R. G.: Debris-flow mobilization from landslides, Annu. Rev. Earth Planet Sc., 25, 85138, 1997.

Jakob, M.: A size classification for debris flows, Eng. Geol., 79, 151-161, 2005.
Jakob, M., Bovis, M., and Oden, M.: The significance of channel recharge rates for estimating debris-flow magnitude and frequency, Earth Surf. Proc. Land, 30, 755-766, 2005.

Kean, J. W., Staley, D. M., Leeper, R. J., Schmidt, K. M., and Gartner, J. E.: A low-cost method to measure the timing of postfire flash floods and debris flows relative to rainfall, Water Resour. Res., 48, W05516, https://doi.org/10.1029/2011WR011460, 2012.

Kean, J. W., McCoy, S. W., Tucker, G. E., Staley, D. M., and Coe, J. A.: Runoff-generated debris flows: observations and modeling of surge initiation, magnitude, and frequency, J. Geophys. Res.Earth, 118, 2190-2207, 2013.

Korup, O. and Clague, J. J.: Natural hazards, extreme events, and mountain topography, Quaternary Sci. Rev., 28, 977-990, 2009.

Lewkowicz, A. G. and Harris, C.: Frequency and magnitude of active-layer detachment failures in discontinuous and continuous permafrost, northern Canada, Permafrost Periglac., 16, 115-130, 2005.

Li, Q. Y. and Xie, Z. C.: Analysis on the characteristics of the vertical lapse rates of temperature. Taking Tibetan Plateau and its adjacent area as an example, J Shihezi University (Natural Science), 24, 719-723, 2006 (in Chinese).

Liu, J. J., Cheng, Z. L., and Su, P. C.: The relationship between air temperature fluctuation and Glacial Lake outburst floods in Tibet, China, Quatern. Int., 321, 78-87, 2014.

Liu, Y.: Research on the Typical Debris Flows Chain Based On RS in Palongzangbu Basin of Tibet, MS thesis, Chengdu University of Science And Technology, 2013 (in Chinese).

Lu, R. R. and Li, D.J.: Ice-snow-melt debris flows in the Dongru Longba, Bomi county, Xizang, J. Glaciol. Geocryol., 11, 148160, 1989 (in Chinese).

McColl, S. T.: Paraglacial rock-slope stability, Geomorphology, 153-154, 1-16, 2012

Noetzli, J., Gruber, S., Kohl, T., Salzmann, N., and Haeberli, W. Three-dimensional distribution and evolution of permafrost temperatures in idealized high-mountain topography, J. Geophys. Res., 112, F02S13, https://doi.org/10.1029/2006JF000545, 2007.

Prancevic, J. P., Lamb, M. P., and Fuller, B. M.: Incipient sediment motion across the river to debris-flow transition, Geology, 42, 191-194, 2014.

Rahardjo, H., Leong, E. C., and Rezaur, R. B.: Effect of antecedent rainfall on pore-water pressure distribution characteristics in residual soil slopes under tropical rainfall, Hydrol. Process., 22, 506-523, 2008.

Rango, A. and Martinec, J.: Revisiting the degree-day method for snowmelt computations, JAWRA, J. Am. Water Resour. As., 31, 657-669, 1995.

Recking, A.: Theoretical development on the effect of changing flow hydraulics on incipient bed load motion, Water Resour. Res., 45, W04401, https://doi.org/10.1029/2008WR006826, 2009.

Rengers, F. K., McGuire, L. A., Kean, J. W., and Hobley, D. E.: Model simulations of flood and debris flow timing in steep catchments after wildfire, Water Resour. Res., 52, 6041-6061, 2016.

Rist, A.: Hydrothermal Processes within the Active Layer above Alpine Permafrost in Steep Scree Slopes and Their Influence on Slope Stability, PhD Thesis, Swiss Federal Institute for Snow and Avalanche Research and University of Zurich, 168 pp., 2007. 
Ryzhkin, I. A. and Petrenko, V. F.: Physical mechanisms responsible for ice adhesion, J. Phys. Chem. B, 101, 6267-6270, 1997.

Sassa, K. and Wang, G. H.: Mechanism of Landslide-Triggered Debris Flows: Liquefaction Phenomena due to the Undrained Loading of Torrent Deposits, Debris-flow Hazards and Related Phenomena, Springer, Berlin, Heidelberg, 81-104, 2005.

Sattler, K., Keiler, M., Zischg, A., and Schrott, L.: On the connection between debris flow activity and permafrost degradation: a case study from the Schnalstal, South Tyrolean Alps, Italy, Permafrost Periglac., 22, 254-265, 2011.

Schneuwly-Bollschweiler, M. and Stoffel, M.: Hydrometeorological triggers of periglacial debris flows in the Zermatt valley (Switzerland) since 1864, J. Geophys. Res., 117, F02033, https://doi.org/10.1029/2011JF002262, 2012.

Shang, Y. J., Yang, Z. F., Li, L., Liu, D. A., Liao, Q., and Wang, Y.: A super-large landslide in Tibet in 2000: background, occurrence, disaster, and origin, Geomorphology, 54, 225-243, 2003.

Springman, S. M., Jommi, C., and Teysseire, P.: Instabilities on moraine slopes induced by loss of suction: a case history, Géotechnique, 53, 3-10, 2003.

Stoffel, M. and Huggel, C.: Effects of climate change on mass movements in mountain environments, Prog. Phys. Geog., 36, 421-439, 2012.

Stoffel, M., Bollschweiler, M., and Beniston, M.: Rainfall characteristics for periglacial debris flows in the Swiss Alps: past incidences-potential future evolutions, Climatic Change, 105, 263-280, 2011.

Takahashi, T.: Debris Flow: Mechanics, Prediction and Countermeasures, CRC Press, Boca Raton, FL, 2014.

Takeuchi, Y., Kayastha, R. B., and Nakawo, M.: Characteristics of ablation and heat balance in debris-free and debris-covered areas on Khumbu Glacier, Nepal Himalayas, in the pre-monsoon season, Seattle, Washington, USA, IAHS-AISH P., 264, 53-62, 2000 .
The Ministry of Land and Resources P. R. C.: China geological hazard Bulletin, September Edn., 2010.

Theule, J. I., Liébault, F., Loye, A., Laigle, D., and Jaboyedoff, M.: Sediment budget monitoring of debris-flow and bedload transport in the Manival Torrent, SE France, Nat. Hazards Earth Syst. Sci., 12, 731-749, https://doi.org/10.5194/nhess-12-7312012, 2012.

Tognacca, C., Bezzola, G. R., and Minor, H. E.: Threshold criterion for debris-flow initiation due to channel bed failure, in: Proceedings Second International Conference on Debris Flow Hazards Mitigation, Prediction and Assessment, edited by: Wieczoreck, G. F., Taipei, 89-97, 2000.

Yang, W., Yao, T., Xu, B., Ma, L., Wang, Z., and Wan, M.: Characteristics of recent temperate glacier fluctuations in the Parlung Zangbo River basin, southeast Tibetan Plateau, Chinese Sci. Bull., 55, 2097-2102, 2010.

Yang, W., Guo, X., Yao, T., Zhu, M., and Wang, Y.: Recent accelerating mass loss of southeast Tibetan glaciers and the relationship with changes in macroscale atmospheric circulations, Clim. Dynam., 47, 805-815, 2016.

Yao, T. D., Thompson, L., Yang, W., Yu, W., Gao, Y., Guo, X., Yang, X., Duan, K., Zhao, H., Xu, B., Pu, J., Lu, A., Xiang, Y., Kattel, D. B., and Joswiak, D.: Different glacier status with atmospheric circulations in Tibetan Plateau and surroundings, Nature Climate Change, 2, 663-667, 2012.

Yuan, G. X., Ding, R. W., Shang, Y. J., and Zeng, Q. L.: Genesis of the Quaternary accumulations along the Palong section of the Sichuan-Tibet Highway and Their distribution regularities, Geology and Exploration, 48, 170-176, 2012 (in Chinese). 